\title{
Intraoperative antegrade intravascular ultrasound examination in acute type $A$ aortic dissection with suspected visceral malperfusion
}

Mehmet Alagoz, MD, Yuki Ikeno, MD, PhD, Akiko Tanaka, MD, PhD, Anthony L. Estrera, MD, and Rana O. Afifi, MD, Houston, Tex

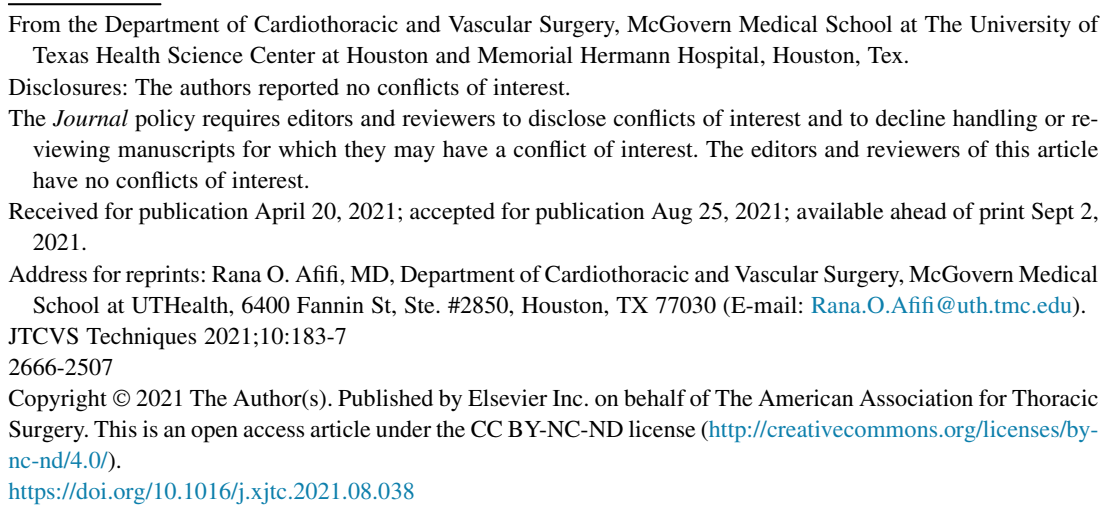

Visceral malperfusion remains a devastating complication of acute type A aortic dissection (ATAD). ${ }^{1}$ Although most malperfusions spontaneously resolve following central aortic repair for ATAD, ${ }^{2}$ some may require an additional intervention for persistent ischemia. However, the configuration of the distal aorta and perfusion status of the visceral branches following the repair are unpredictable. Intraoperative assessment for malperfusion following the central repair has not been established. Since 2013, we have used intraoperative antegrade intravascular ultrasound (IVUS) via ascending graft for patients with type A aortic dissection with suspected visceral malperfusion. In this report, we describe our technique and its safety and efficacy.

\section{PATIENTS AND METHODS}

This is a retrospective review between January 2013 and December 2017; 15 of 192 patients with type A aortic dissection $(8 \%)$ underwent intraoperative IVUS examination at our institution. Clinical data were collected and analyzed retrospectively. The suspicion for visceral malperfusion was based on clinical symptoms, laboratory (eg, elevated serum lactate level), or computed tomography findings (eg, compressed true lumen at the level of the visceral portion, and nonperfused visceral branches). Data collection and analysis were approved by The McGovern Medical School at UTHealth's Committee for the Protection of Human Subjects (IRB: HSC-MS-03-077).

\section{OPERATIVE PROCEDURE}

Our approach for ATAD has been reported previously. ${ }^{3}$ To summarize, the dissected ascending aorta and proximal arch are replaced and entry tear is resected under profound hypothermia circulatory arrest with retrograde cerebral (Figure 1).

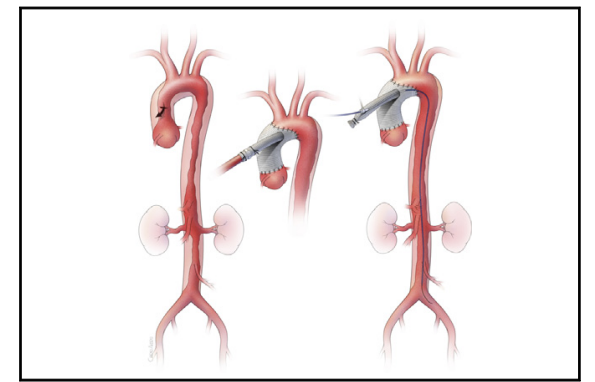

IVUS allows immediate evaluation of the distal aortic configuration and branch vessels.

CENTRAL MESSAGE

Intraoperative antegrade intravascular ultrasound is a feasible and safe procedure to assess detailed configuration of the true lumen and visceral branches after central repair.

See Commentary on page 188.

perfusion, using a single, sidearm Dacron graft. The systemic circulation is re-established via the perfusion sidearm branch after the distal anastomosis. Then, the proximal anastomosis is performed during warming. After the patient is weaned off the cardiopulmonary bypass, pulsatile flow to the body is regained. An 8-French sheath is inserted to the sidearm perfusion branch by the Seldinger technique. Transesophageal echocardiogram is used to guide the 0.035-inch guidewire into the true lumen of the descending thoracic aorta. Then, an IVUS catheter is advanced over the wire-all the way to the iliac artery in antegrade fashion. IVUS imaging is obtained using a Volcano s5 Imaging System and a Visions PV .035 Digital IVUS Catheter (Philips North America Co, Cambridge, Mass). True lumen configuration and flap extension to visceral arteries are evaluated. Based on the IVUS finding, additional procedures are performed, if required 


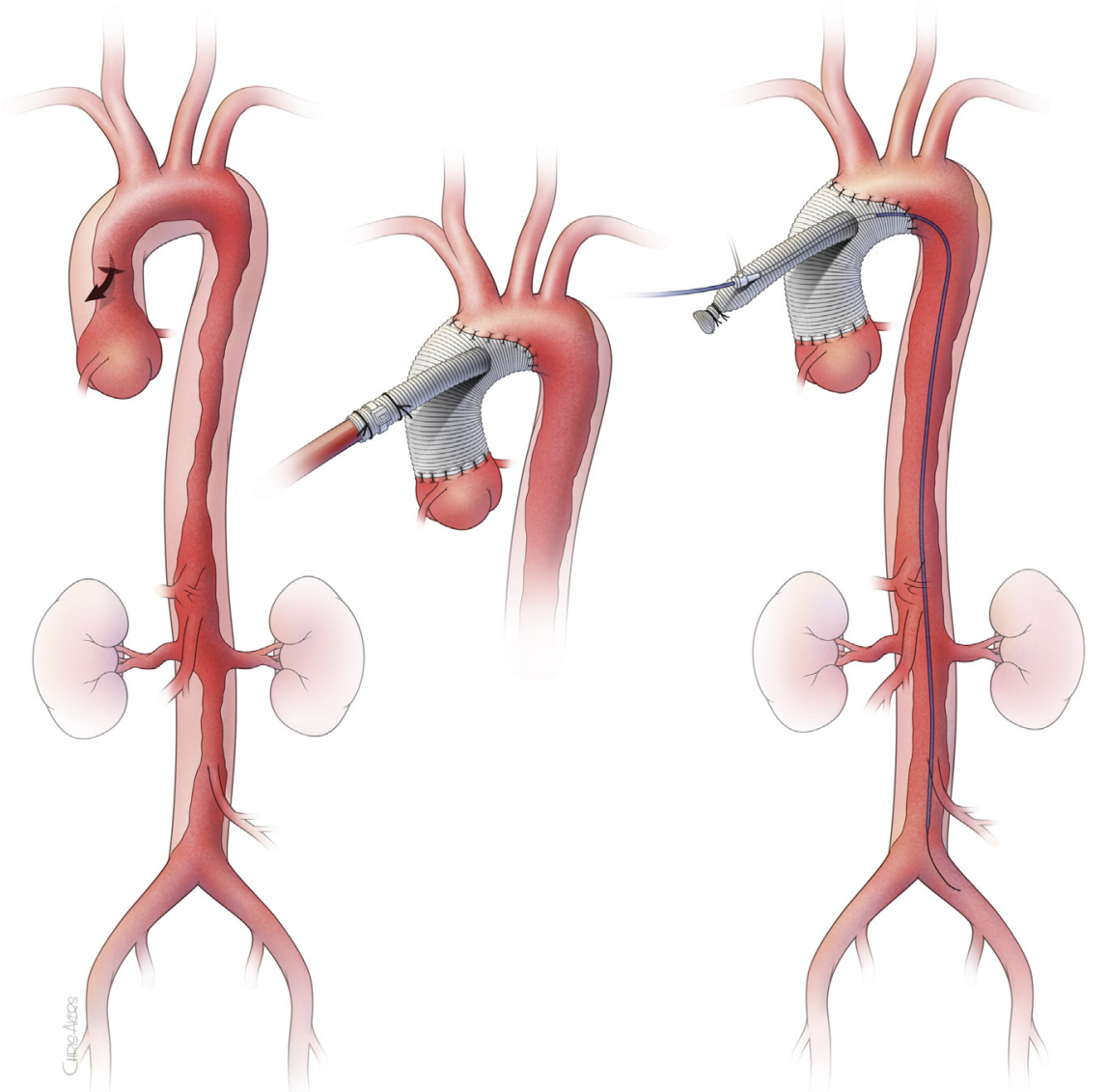

FIGURE 1. Surgical approach of intraoperative antegrade intravascular ultrasound. Intraoperative intravascular ultrasound through the perfusion sidearm branch allows immediate evaluation of the distal aortic configuration and branch vessel status following central repair of the aortic dissection in patients suspected for malperfusion syndrome to guide further treatment. The access through the sidearm requires no additional arterial access and allows reliable engagement to the true lumen of the dissected aorta without technical difficulties.

\section{RESULTS}

Patient characteristics are shown in Table 1. Technical success of the IVUS examination was seen in all patients. After the central repair, true lumen was expanded in 11 patients (73\%). Three patients (Nos. 5, 6, and 15) had compressed true lumen at the level of the visceral aorta and underwent thoracic endovascular aortic repair after upsizing the sheath in the sidearm. One patient (No. 4) received axillary-bifemoral bypass due to collapsed true lumen limited to the infrarenal abdominal aorta (Figure 2). All 4 had improved true lumen expansion and peripheral perfusion after the additional interventions (Figure 3), which was also confirmed by IVUS. One patient (No. 9) received exploratory laparotomy with left colectomy, despite good pulsation on visceral vessels. This patient had a left low anterior resection for colon cancer, which likely contributed to the low reserve to the remaining left colon. The damage was irreversible at the time of presentation. Operative mortality was seen in 2 patients
$(13 \%)$, whereas 12 patients recovered and were discharged home and 1 (No. 4) was discharged to hospice care due to being comatose.

\section{DISCUSSION}

The use of IVUS in aortic dissection was first described more than 30 years $\mathrm{ago}^{4}$ and with the growth of endovascular applications, has gained in importance in treating patients with dissection. Transesophageal echocardiogram is routinely used during ATAD repair and may be used to evaluate the proximal descending thoracic aorta but not the distal descending or thoracoabdominal aorta. The advantages of IVUS examination in aortic dissection are the real-time assessment of the true and false lumen configurations throughout the aorta and iliac arteries ${ }^{5}$ and visualization of the visceral branches. Antegrade approach after the central repair provides easy and reliable access to the true lumen of the dissected aorta, allowing us to inspect the true lumen 
TABLE 1. Patient demographics and outcomes

\begin{tabular}{|c|c|c|c|c|c|c|c|c|c|c|c|}
\hline \multirow[b]{2}{*}{ Patient } & \multirow[b]{2}{*}{$\begin{array}{c}\text { Age, } \\
\mathbf{y}\end{array}$} & \multirow[b]{2}{*}{ Sex } & \multirow[b]{2}{*}{$\begin{array}{l}\text { Malperfusion } \\
\text { symptoms }\end{array}$} & \multirow{2}{*}{$\begin{array}{c}\text { Occlusion/ } \\
\text { compression } \\
\text { of the true } \\
\text { lumen }\end{array}$} & \multicolumn{2}{|c|}{ Preoperative } & \multirow[b]{2}{*}{ ET } & \multirow[b]{2}{*}{ IVUS findings } & \multirow[b]{2}{*}{$\begin{array}{c}\text { Additional } \\
\text { interventions }\end{array}$} & \multirow[b]{2}{*}{$\begin{array}{c}\text { Ex } \\
\text { Lap }\end{array}$} & \multirow[b]{2}{*}{ Outcomes } \\
\hline & & & & & $\begin{array}{c}\text { eGFR, } \\
\mathrm{mL} / \mathrm{min} / \\
1.73 \mathrm{~m}^{2}\end{array}$ & $\begin{array}{c}\text { Lactic } \\
\text { acid, } \\
\mathrm{mg} / \mathrm{dL}\end{array}$ & & & & & \\
\hline$\# 1$ & 64 & M & None & $\mathrm{R}$ renal & 22 & 5.3 & - & $\begin{array}{l}\text { Expanded true lumen } \\
\text { of descending aorta, } \\
\text { patent visceral } \\
\text { branches }\end{array}$ & None & - & Discharged home \\
\hline \#2 & 48 & M & Abdominal pain & $\mathrm{R}$ renal & 59 & 3.7 & - & $\begin{array}{l}\text { Expanded true lumen } \\
\text { of descending aorta, } \\
\text { patent visceral } \\
\text { branches }\end{array}$ & None & - & Discharged home \\
\hline \#3 & 39 & M & $\begin{array}{l}\text { Abdominal pain, } \\
\text { diminished } \\
\text { distal pulses }\end{array}$ & $\begin{array}{l}\text { Celiac, SMA } \\
\text { L renal }\end{array}$ & 77 & 6.5 & - & $\begin{array}{l}\text { Expanded true lumen } \\
\text { of descending aorta, } \\
\text { patent visceral } \\
\text { branches }\end{array}$ & None & - & Discharged home \\
\hline \#4 & 50 & M & $\begin{array}{l}\text { Paraplegia with } \\
\text { palpable femoral } \\
\text { pulses }\end{array}$ & $\begin{array}{l}\text { Descending } \\
\text { aorta }\end{array}$ & 54 & 7.2 & - & $\begin{array}{l}\text { Compressed true } \\
\text { lumen at the level of } \\
\text { the abdominal } \\
\text { aorta, patent } \\
\text { visceral branches }\end{array}$ & $\begin{array}{c}\text { Ax-biFem } \\
\text { bypass }\end{array}$ & - & $\begin{array}{l}\text { Discharged to } \\
\text { hospice care }\end{array}$ \\
\hline \#5 & 71 & $\mathrm{~F}$ & $\begin{array}{l}\text { Metabolic acidosis, } \\
\text { diminished distal } \\
\text { pulses }\end{array}$ & $\begin{array}{l}\text { Descending } \\
\text { aorta }\end{array}$ & 33 & $>12$ & - & $\begin{array}{l}\text { Compressed true } \\
\text { lumen in the } \\
\text { visceral portion of } \\
\text { abdominal aorta, } \\
\text { compressed } \\
\text { visceral branches }\end{array}$ & TEVAR & - & $\begin{array}{l}\text { Death due to } \\
\text { cardiogenic } \\
\text { shock on POD } 1\end{array}$ \\
\hline \#6 & 44 & M & $\begin{array}{l}\text { Abdominal and left } \\
\text { leg pain }\end{array}$ & $\begin{array}{l}\text { Lower } \\
\text { extremities }\end{array}$ & 52 & $>12$ & - & $\begin{array}{l}\text { Compressed true } \\
\text { lumen of left } \\
\text { common iliac } \\
\text { artery, patent } \\
\text { visceral branches }\end{array}$ & $\begin{array}{l}\text { TEVAR + } \\
\text { iliac stents }+ \\
\text { fasciotomy }\end{array}$ & + & Discharged home \\
\hline \#7 & 50 & $\mathrm{~F}$ & $\begin{array}{l}\text { Abdominal and right } \\
\text { leg pain }\end{array}$ & Celiac & 58 & 3.6 & - & $\begin{array}{l}\text { Expanded true lumen } \\
\text { of descending aorta, } \\
\text { patent visceral } \\
\text { branches }\end{array}$ & None & - & Discharged home \\
\hline \#8 & 86 & M & Abdominal pain & Celiac & 25 & 8.5 & - & $\begin{array}{l}\text { Expanded true lumen } \\
\text { of descending aorta, } \\
\text { patent visceral } \\
\text { branches }\end{array}$ & None & - & Discharged home \\
\hline$\# 9$ & 71 & M & Abdominal pain & SMA, L renal & 28 & 6.8 & - & $\begin{array}{l}\text { Expanded true lumen } \\
\text { of descending aorta, } \\
\text { patent visceral } \\
\text { branches }\end{array}$ & Left colectomy & + & $\begin{array}{l}\text { Death from MOF } \\
\text { on POD\#13 }\end{array}$ \\
\hline$\# 10$ & 62 & M & Abdominal pain & Celiac, L renal & 64 & 5 & + & $\begin{array}{l}\text { Expanded true lumen } \\
\text { of descending aorta, } \\
\text { patent visceral } \\
\text { branches }\end{array}$ & None & - & Discharged home \\
\hline \#11 & 64 & M & Abdominal pain & Celiac & 90 & 7.8 & - & $\begin{array}{l}\text { Expanded true lumen } \\
\text { of descending aorta, } \\
\text { patent visceral } \\
\text { branches }\end{array}$ & None & - & Discharged home \\
\hline
\end{tabular}


TABLE 1. Continued

\begin{tabular}{|c|c|c|c|c|c|c|c|c|c|c|c|}
\hline \multirow[b]{2}{*}{ Patient } & \multirow[b]{2}{*}{$\begin{array}{c}\text { Age, } \\
\mathbf{y}\end{array}$} & \multirow[b]{2}{*}{ Sex } & \multirow[b]{2}{*}{$\begin{array}{c}\text { Malperfusion } \\
\text { symptoms }\end{array}$} & \multirow{2}{*}{$\begin{array}{l}\text { Occlusion/ } \\
\text { compression } \\
\text { of the true } \\
\text { lumen }\end{array}$} & \multicolumn{2}{|c|}{ Preoperative } & \multirow[b]{2}{*}{ ET } & \multirow[b]{2}{*}{ IVUS findings } & \multirow[b]{2}{*}{$\begin{array}{c}\text { Additional } \\
\text { interventions }\end{array}$} & \multirow[b]{2}{*}{$\begin{array}{c}\text { Ex } \\
\text { Lap }\end{array}$} & \multirow[b]{2}{*}{ Outcomes } \\
\hline & & & & & $\begin{array}{l}\text { eGFR, } \\
\mathrm{mL} / \mathrm{min} / \\
1.73 \mathrm{~m}^{2}\end{array}$ & $\begin{array}{l}\text { Lactic } \\
\text { acid, } \\
\mathrm{mg} / \mathrm{dL}\end{array}$ & & & & & \\
\hline$\# 12$ & 57 & M & Abdominal pain & L renal & 74 & 6.2 & + & $\begin{array}{l}\text { Expanded true lumen } \\
\text { of descending aorta, } \\
\text { patent visceral } \\
\text { branches }\end{array}$ & None & - & Discharged home \\
\hline \#13 & 58 & M & Abdominal pain & Celiac & 83 & 3.2 & - & $\begin{array}{l}\text { Expanded true lumen } \\
\text { of descending aorta, } \\
\text { patent visceral } \\
\text { branches }\end{array}$ & None & - & Discharged home \\
\hline \#14 & 65 & M & None & L renal & 72 & 3.2 & - & $\begin{array}{l}\text { Expanded true lumen } \\
\text { of descending aorta, } \\
\text { patent visceral } \\
\text { branches }\end{array}$ & None & - & Discharged home \\
\hline \#15 & 57 & M & $\begin{array}{l}\text { Abdominal pain, } \\
\text { numbness in } \\
\text { left leg }\end{array}$ & Celiac, SMA & 50 & 8.2 & - & $\begin{array}{l}\text { Compressed true } \\
\text { lumen in the } \\
\text { visceral portion of } \\
\text { abdominal aorta, } \\
\text { compressed } \\
\text { visceral branches }\end{array}$ & TEVAR & - & Discharged home \\
\hline
\end{tabular}

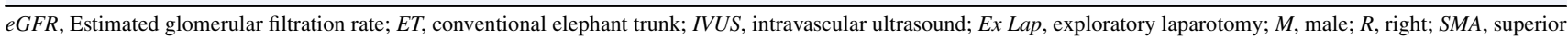
mesenteric artery; $L$, left; Ax-biFem, axillary-bifemoral bypass; $F$, female; TEVAR, thoracic endovascular aortic repair; POD, postoperative day; $M O F$, multiorgan function.

expansion, but also can be used in cases of antegrade placement of a stent graft in the descending aorta to confirm deployment in the true lumen. We believe that patients with high suspicion for malperfusion at presentation, based on clinical, laboratory, and imaging, may benefit from an antegrade IVUS study if additional interventions, such as thoracic endovascular aortic repair or exploratory laparotomy, are needed. Antegrade IVUS allows us to avoid the use of contrast agent and additional arterial access. The limitation of the study is the IVUS system we used currently does not allow Doppler imaging, so we could not directly evaluate the flow. The use of a Doppler-available device may further expedite the evaluation, but further study is required.

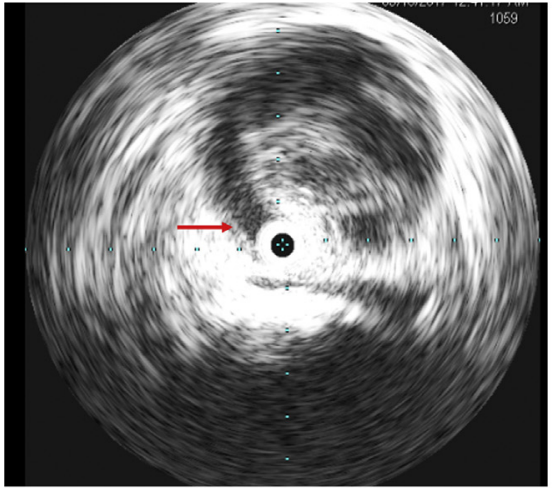

A

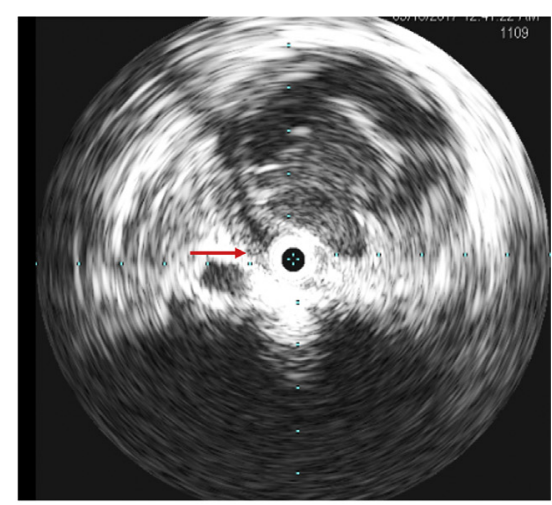

B

FIGURE 2. Intravascular ultrasound images of compressed true lumen. A and B, Intravascular ultrasound images of compressed true lumen (red arrows) at the abdominal aorta after central repair of type A aortic dissection. 


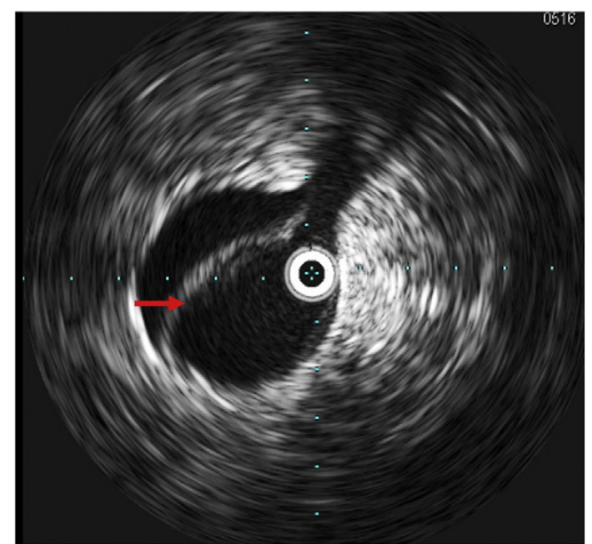

A

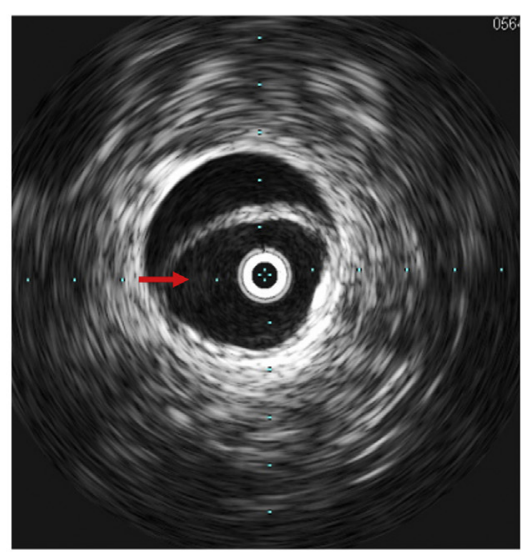

B

FIGURE 3. Intravascular ultrasound images of expanded true lumen. A and B, Intravascular ultrasound images of expanded true lumen (red arrows) at the abdominal aorta after central repair of type A aortic dissection.

\section{CONCLUSIONS}

Our study demonstrates the feasibility and safety of intraoperative IVUS examination through the side branch of the ascending Dacron graft. An immediate evaluation of the residual dissection using IVUS provides useful information for our decision-making in treating patients with suspected malperfusion syndrome.

\section{References}

1. Tanaka A, Estrera AL. Mesenteric malperfusion: the insidious, dreadful enemy. Semin Thorac Cardiovasc Surg. 2017;29:179-80.
2. Charlton-Ouw KM, Sritharan K, Leake SS, Sandhu HK, Miller CC III, Azizzadeh A, et al. Management of limb ischemia in acute proximal aortic dissection. J Vasc Surg. 2013;57:1023-9.

3. Estrera AL, Miller CC III, Lee TY, Shah P, Safi HJ. Ascending and transverse aortic arch repair: the impact of retrograde cerebral perfusion. Circulation. 2008;118:S160-6

4. Belkin N, Jackson BM, Foley PJ, Damrauer SM, Kalapatapu V, Golden MA, et al The use of intravascular ultrasound in the treatment of type B aortic dissection with thoracic endovascular aneurysm repair is associated with improved longterm survival. J Vasc Surg. 2020;72:490-7.

5. Koschyk DH, Nienaber CA, Knap M, Hofmann T, Kodolitsch YV, Skriabina V, et al. How to guide stent-graft implantation in type B aortic dissection? Comparison of angiography, transesophageal echocardiography, and intravascular ultrasound. Circulation. 2005;112:I260-4. 